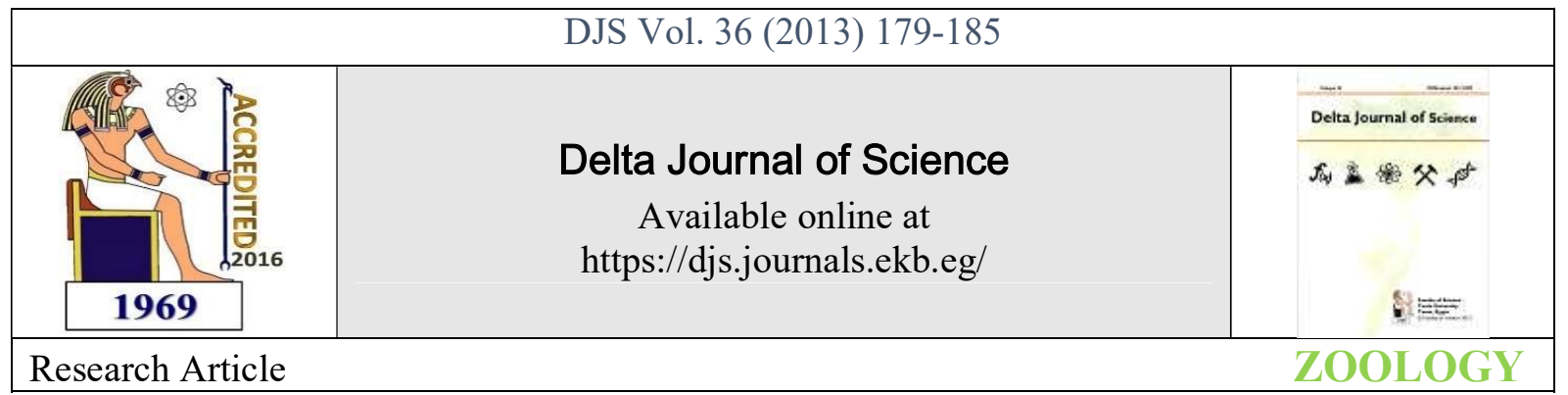

\title{
Characterization of ITS1 gene of Leishmania infantum isolated from Iraqi patients with visceral leishmaniasis by PCR- RFLP and sequencing methods.
}

\author{
Ilham A. Majeed1 Fatemeh Gaffarifar2 Nada Al-Bashier3 \\ 1. Medical Laboratory Dept. College of Health \& Medical Technology/ Baghdad/Iraq. \\ 2 Parasitology and Entomology Dept., Faculty of Medical Sciences, Tarbiat Modares University, \\ P.O.Box 14115-331. \\ 3. Medical Research Center/ College of Medicine/ Al-Nehrain University/ Baghdad/ Iraq.
}

\begin{abstract}
For the best of our knowledge, there is no information about molecular characterization of Iraqi isolates of visceral leishmaniasis, the present work aimed to characterize three different Iraqi isolates of Leishmania infantum by polymerase chain reaction (PCR), restriction fragment length polymorphism (RFLP) and sequencing methods.

Three isolates from bone marrow of Iraqi patients infected with kala azar were used in this study. The isolates were already diagnosed by isoenzyme as Leishmania infantum. Patients were inhabiting different parts of Baghdad. The samples after microscopic examination were cultured on modified NNN media. Then DNA was extracted for amplifying ITS1 (internal transcribed spacer 1) gene by PCR. Identification of samples was studied using RFLP (digestion with Apo1 restriction enzyme) and sequencing of PCR products.

The PCR of all samples showed a band under about $500 \mathrm{bp}$. The results by using PCR-RFLP method showed no restriction with digestion with Apo1 restriction enzyme. The results of sequencing showed differences with all separated gene from Leishmania infantum in the gene bank.

In this study we found that the sequences of ITS1 gene of Leishmania infantum separated from Iraqi patients are different from other samples, as there is no similarity with Leishmania infantum (MHOM/TN/80/IPI1). The more similarity is with the Iranian isolate of Leishmania infantum (MCAN/IR/97/LON) with 41\%, whereas the similarity with Crithidia luciliae internal transcribed spacer 1 , ITS1 is $96 \%$.
\end{abstract}

Key words: Visceral leishmaniasis, PCR-RFLP, sequencing, Iraq

\section{INTRODUCTION}

Leishmaniasis is endemic in 88 countries and 12 million people per year have been estimated to be at risk of infection. Leishmaniasis forms a spectrum of diseases ranging from benign, self-healing skin ulcer to overwhelming lethal systemic infection (1).

The leishmaniasis comprise a group of diseases that display widely different clinical manifestations in humans, which depend not only on the species initiating infection but also on the general health and genetic make-up of the infected individual (2).

Visceral leishmaniasis is a serious health problem and an important endemic disease in Iraq. During the last years there was an increase in visceral leishmaniasis cases in Iraq (3).

Majeed et al. (2012) reported that in Iraq, visceral leishmaniasis incidence per 100000 population was $2 \cdot 6$ in $2007,3 \cdot 1$ in 2008 , and $4 \cdot 8$ in 2009 , mostly in children aged $<5$ years (4).

In Iraq visceral leishmaniasis is usually detected in infants and children $(5,6)$. According to Zukerman \& Lainson at 1977, 
visceral leishmaniasis in Iraq is considered to be of infantile type (7).

Correct identification of the etiologic agent of leishmaniasis is important for clinical, epidemiologic reasons, prevention, and treatment. Therefore, molecular characterization based on partial sequences of Leishmania species is important.

ITS1 is a suitable target for detection, identification and characterization of Leishmania spp for this reason, this gene was used in this study. In the present study, PCR and sequencing of ITS1gene were employed to study visceral leishmaniasis of the Iraqi isolates.

\section{Materials and Methods}

\section{1) Isolates:}

Three Iraqi isolates of L. infantum was used in this study, they were collected by bone marrow aspirate from three patients living in different parts of rural areas of Baghdad.

Those patients were all less than five years old, one girl and two boys.

The isolates were cultivated on liquid NNN medium containing RPMI

so that large number of promastigote can be harvested for DNA extraction,

also Leishmania infantum strain (MHOM/TN/80/IPI1) was cultivated and used as positive control.

\section{2) DNA extraction:}

About $2 \times 106$ of promastigotes of each isolates and MHOM/TN/80/IPI1 strain were initially washed with phosphate buffered saline (PBS).

The procedure of the extraction of DNA was followed according to the manufacturer instruction of the kit (Bioneer Corporation).

The DNA extraction products were detected in $0.8 \%$ agarose gel and photographed. The results showed that concentration of the extracted DNA was high.

\section{3) PCR amplification and gel electrophoresis}

Genomic DNA from promastigotes of all isolates and Leishmania infantum strain (MHOM/TN/80/IPI1) were used as templates to amplify the ITS1 gene by PCR. The reaction was performed in $25 \mu \mathrm{l}$ of the solution containing, $3 \mu \mathrm{l}$ of template DNA, $0.5 \mu 1$ of dNTP (with concentration $10 \mathrm{mM}$ and final concentration of $200 \mu \mathrm{M}), 0.5 \mu \mathrm{l}$ of Taq DNA polymerase (with concentration $5 \mathrm{Unit} / \mathrm{ml}$ ), $2.5 \mu 1$ of $10 \mathrm{X}$ PCR buffer, $0.75 \mu 1$ of $\mathrm{MgCl} 2(50 \mathrm{mM}), 15.75 \mu 1$ of distilled water and $1 \mu 1$ of each of primers $(10 \mathrm{Pmol} / \mu \mathrm{l})$.

The primer sequences that we used in this study were as follows (Spanakos et al., 2008) (8):

\section{LeF, 5 _-TCCGCCCGAAAGTTCACCGATA-3and \\ LeR, 5_CCAAGTCATCCATCGCGACACG-3_;}

These primers could detect $18 \mathrm{~S}$ ribosomal RNA gene, partial sequence; internal transcribed spacer 1, complete sequence; and $5.8 \mathrm{~S}$ ribosomal RNA gene, partial sequence of Leishmania spp.

The PCR program was as follow: $5 \mathrm{~min}$ at $94 \mathrm{oC}$ for initial denaturation step, then 30 cycles of denaturation at $94 \mathrm{oC}$ for 1 $\mathrm{min}$, annealing at $54 \mathrm{oC}$ for $30 \mathrm{~s}$, an extension at $72 \mathrm{oC}$ for $45 \mathrm{~s}$, and a final extension at $72 \mathrm{oC}$ for $5 \mathrm{~min}$.
The PCR products were analyzed by electrophoresis on $1.5 \%$ agarose gels, visualized by UV illumination and finally photographed.

4) Digestion with restriction endonuclease enzyme (RFLP)

Based on the sequences of L. infantum retrieved from Gen Bank, we expected that ApoI could digest the PCR product, then ApoI (Fermentase co.) was selected as a suitable enzyme used for all L. donovani complex (Spanakos et al., 2008)(8).

RFLP was performed according to the methods described by (Marfurt et al., 2003) (9). We provided total $31 \mu \mathrm{l}$ volume, include $10 \mu \mathrm{l}$ of PCR products (0.1-0.5 $\mu \mathrm{g}$ of DNA), $18 \mu \mathrm{l}$ of nuclease-free water, $2 \mu \mathrm{l}$ of $10 \mathrm{X}$ buffer Tango, and $1 \mu \mathrm{l}$ of ApoI enzyme (Fermentase) at $37^{\circ} \mathrm{C}$ water bath overnight (16 h). The digest was used for electrophoresis on 3.5\% agarose gel. Fragment sizes were estimated by their comparison with bands of $100 \mathrm{bp}$ DNA length standard ladder.

\section{5) DNA sequencing}

The PCR products were excised from a 3.5\% agarose gel and DNA was isolated using the QIA quick Gel Extraction Kit (Qiagen), according to the manufacturer's instructions.

All PCR products were sequenced with dideoxy method (Fazapajouh Company) using the PCR primers. Using the Clustal W 1.8 software package.

\section{RESULTS}

\section{Evaluation of the PCR Method}

Based on the results of PCR product in the gel electrophoresis, all isolates showed DNA size $477 \mathrm{bp}$, whereas for MHOM/TN/80/IPI1 was about 380 bp (Fig.1).

\section{RFLP}

The resultant restriction fragments of samples were separated on a $3.5 \%$ agarose gel and difference was observed in amplicon size between isolates and MHOM/TN/80/IPI1 strain

The PCR product of all isolates didn't digested by ApoI (Fig.2) but MHOM/TN/80/IPI1 was digested to two fragments (Fig.3).

\section{Sequencing}

PCR products containing clinical samples and strain MHOM/TN/80/IPI1 were sequenced according to $\mathrm{F}$ and $\mathrm{R}$ primers. All isolates in this study showed similarity sequences (Fig.4).

The results of sequencing indicate that the length of fragments of all clinical isolates were $477 \mathrm{bp}$. It was additionally found out that there is no restriction site of ApoI (AATT) in ITS1 sequences for all clinical isolates, whereas restriction enzyme site was shown in MHOM/TN/80/IPI1 ITS1 sequence.

\section{Discussion}

One of our findings in this study is that the sequences of ITS1 gene of the isolates separated from Iraqi patients are different from other Leishmania infantum strains that registered in gene bank 
ITS1 gene is a target to study the characterization of visceral leishmaniasis because ITS1 sequences are adequately polymorphic to detect different strains (Al-Jawabreh et al., 2006; Fryauff et al., 2006) $(10,11)$ and so we can compare our data with many other study on Leishmania ITS1 sequences that are saved in sequences data banks (Schonian et al., 2003)(12).

In this study it was found that the sequences of ITS1 gene of Leishmania infantum separated from Iraqi patients shows no similarity with Leishmania infantum strain (MHOM/TN/80/IPI1), and moderate similarity with Iranian isolate of Leishmania infantum (MCAN/IR/97/LON) with $41 \%$ (Fig. 5), whereas the similarity with Crithidia luciliae internal transcribed spacer 1, ITS1 is 96\% (Fig.6). We need more molecular studies on other genes of the Iraqi $L$. infantum to explain the similarity with the genus Crithidia luciliae and we may explain this similarity as these isolates are new strain of L. infantum. The sequence variants of ITS1 might be due to the presence of multiple strains/clones or the existence of intragenomic variations in the multicopy ITS1, or a combination of both. Finally, we may need to revise the taxonomy of the Iraqi strain of Leishmania infantum.

\section{Acknowledgment}

This study was performed as part of research activity of staff member of the College of Health \& Medical Technology/ Baghdad/ Iraq and supported by the Dept. of Parasitology \& Entomology at Tarbiat Modares University/ Tehran. Thank is due to the staff of the department of parasitology at Tarbiat Modares University.

The authors declare there is no conflict of interest.

\section{References}

Desjeux, P. Leishmaniasis: current situation and new perspectives. Comp. Immunol., Microbiol. Infect. Dis. (2004); 27: 305-318.

Alexander, J. \& Russell, D. G. (1992). The interaction of Leishmania species with macrophages. Advan. Parasitol. (1992); 31: 175-254.

Rashed, A. Study of Kala-azar in Iraq for the period 19992003[F.I.C.M.S dissertation]. Scientific Council of Community and Family Medicine: Baghdad; (2005).

Majeed, B.; Sobel, J.; Nawar, A.; Badri, S.; Muslim, H. The persisting burden of visceral leishmaniasis in Iraq: data of the National Surveillance System, 1990-2009. Epidemiol Infect. (2012); 4:1- 4.

Hussein, A. Clinical and Laboratories Study for Kala-azar in Thi-Qar City [High Diploma. Thesis]. College of Med. and Heal. Tech. Found. Of Tech. Educ. Baghdad; (2004).

Rifaat, L. Kh. Comparison of serodiagnostic method in Kalaazar with reference to immunoglobulin changes [M.Sc. Thesis]. Baghdad Univ.; (1988).

Zuckerman, A. \& Lainson, R. Leishmania. In: Julius P, Kreier E, editors. Parasitic protozoa Vol. I. New York, San Francisco, London: Academic press; (1977); p. 57-133.

8. Spanakos G. \& Piperaki, E.T. Detection and species identification of Old World Leishmania in clinical samples using a PCR- based method. Trans Roy Soc Trop Med Hyg. (2008); 102:46-53.

Marfurt, J.; Niederwieser, I.; Makia, N.D.; Beck H.P. \& Felger, I. Diagnostic genotyping of Old and New World Leishmania species by PCR-RFLP. Diagn. Microbiol. Infect. Dis. (2003); 46:115-124.

Al-Jawabreh, A.; Schoenian, G.; Hamarsheh, O. \& Presber, W. Clinical diagnosis of cutaneous leishmaniasis: a comparison study between standardized graded direct microscopy and ITS1-PCR of Giemsa-stained smears. Acta Trop. (2006); 99:55-61.

Fryauff, D.J.; Hanafi, H.A.; Klena, .J.D.; Hoel, D.F.; Appawu, M.; Rogers, W,; Puplampu, N.; Odoom, S.; Kweku, M.; Koram, K. Wilson, M.D.; Raczniak, G. \& Boakye, D. Short report: ITS-1 DNA sequence confirmation of Leishmania major as a cause of cutaneous leishmaniasis from an outbreak focus in the Ho district, Southeastern Ghana. Am J. Trop. Med. Hyg. (2006); 75: 502-504.

Schonian, G,; Nasereddin, A.; Dinse, N.; Schweynoch, C.; Schilling, H.D.; Presber, W. \& Jaffe, C.L. PCR diagnosis and characterization of Leishmania in local and imported clinical samples. Diagn. Microbial. Infect. Dis. (2003); 47:349-358.. 


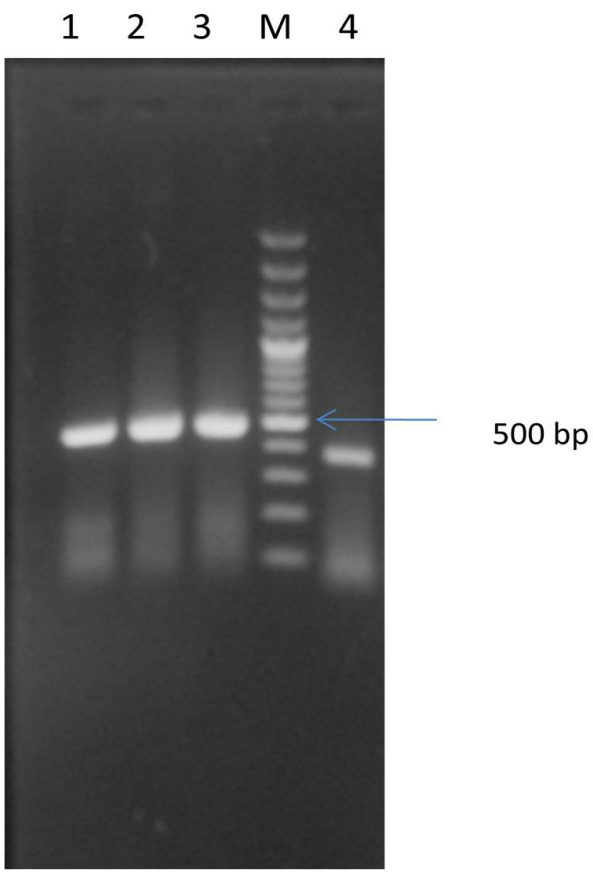

Fig. 1. Agarose gel electrophoresis of PCR products. Lanes 1 to 3: Leishmania infantum isolates from Iraqi patients, (Lane $\mathrm{M}$ ) is a 100 bp ladder.Lanes 4 : Leishmania infantum as standard strain (MHOM/TN/80/IPI1).

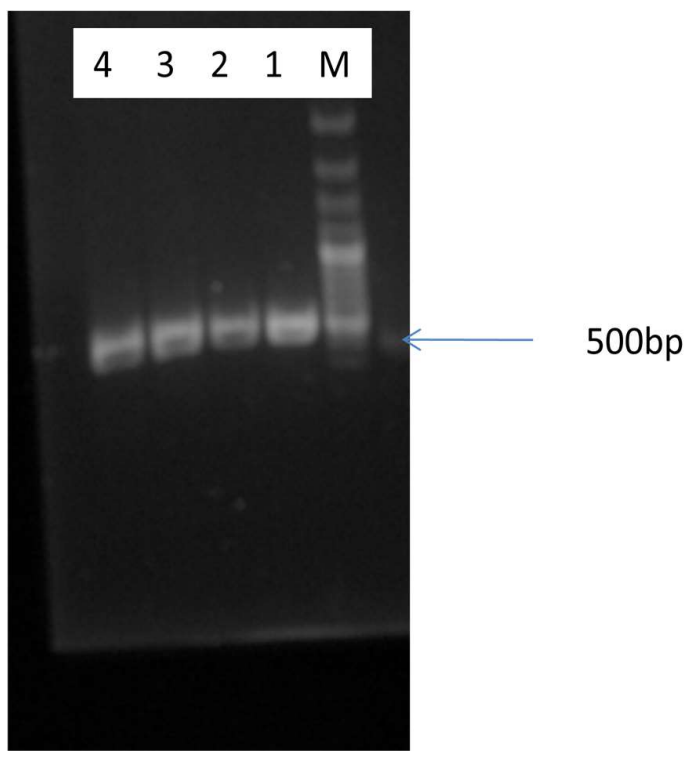


Fig.2: Agarose gel electrophoresis of PCR and RFLP products ( with ApoI enzyme). The marker (lane M) is a 100 bp ladder.Lanes 1\&3 ITS1 from patients isolates before digestion, Lanes 2 and 4 of after digestion with APOI enzyme.

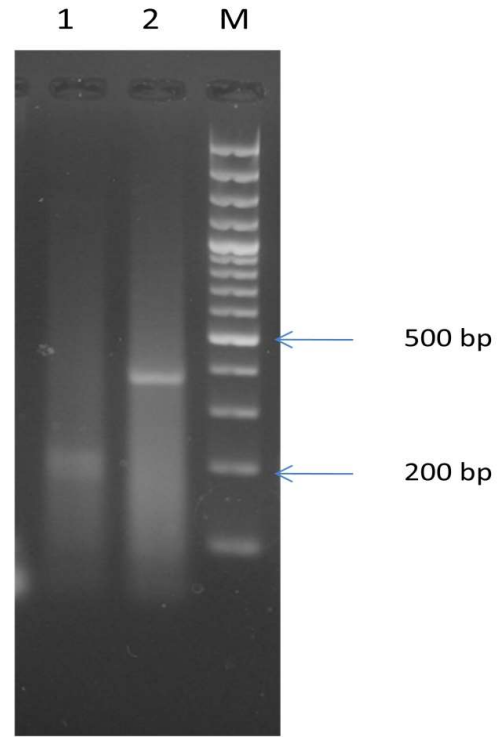

Fig.3: Agarose gel electrophoresis of PCR products and after digestion with ApoI. The marker (lane $\mathrm{M}$ ) is a $100 \mathrm{bp}$ ladder. Lane 1 PCR product of Leishmania infantum strain (MHOM/TN/80/IPI1) after digestion with APOI enzyme, Lanes 2 ITS1 gene before digestion with $A P O$ I enzyme. 
Fig. 4 : Result of PCR product contain18S ribosomal RNA gene, partial sequence; internal transcribed spacer 1, complete sequence; and 5.8S ribosomal RNA gene, partial sequence of visceral leishmaniasis isolate.

CCGATGATACCATACACAAAAACAAAAACCGGAGGGTTTGGGTGTGGCGTGTATGTGTGTA TGTGTGTGCGTGTAAAAAGCGCATGCGCATATATGCATGCATAGTAGTGCCCGGCTCTCTA CGTTGGGAGGAGCGGAAACTAAACATTTCCGTTTCTCTCTAACACATAAACAAACACAACA TAGCCCAGCGCCGTTGCGTGCTTTCTCTCTCTCTCAACTCTCTCTCTTGTGGGGGGTGTTG TGTGTGGGGGTTTGTGCGCGCGTGTGCCGGAACAAGGCCAATCGATGCACGTGTGTGTATT GTATTGTTCTTTCTTAGAGAACGATATAAAAACCGCGTGCATGGATGACGGCTCAAA

Fig.5: The results of sequencing of ITS1 for Iraqi isolates, showed 41\% similarity with Iranian isolates that this similarity is shown in the beginning and the end of ITS1 gene (underline regions).

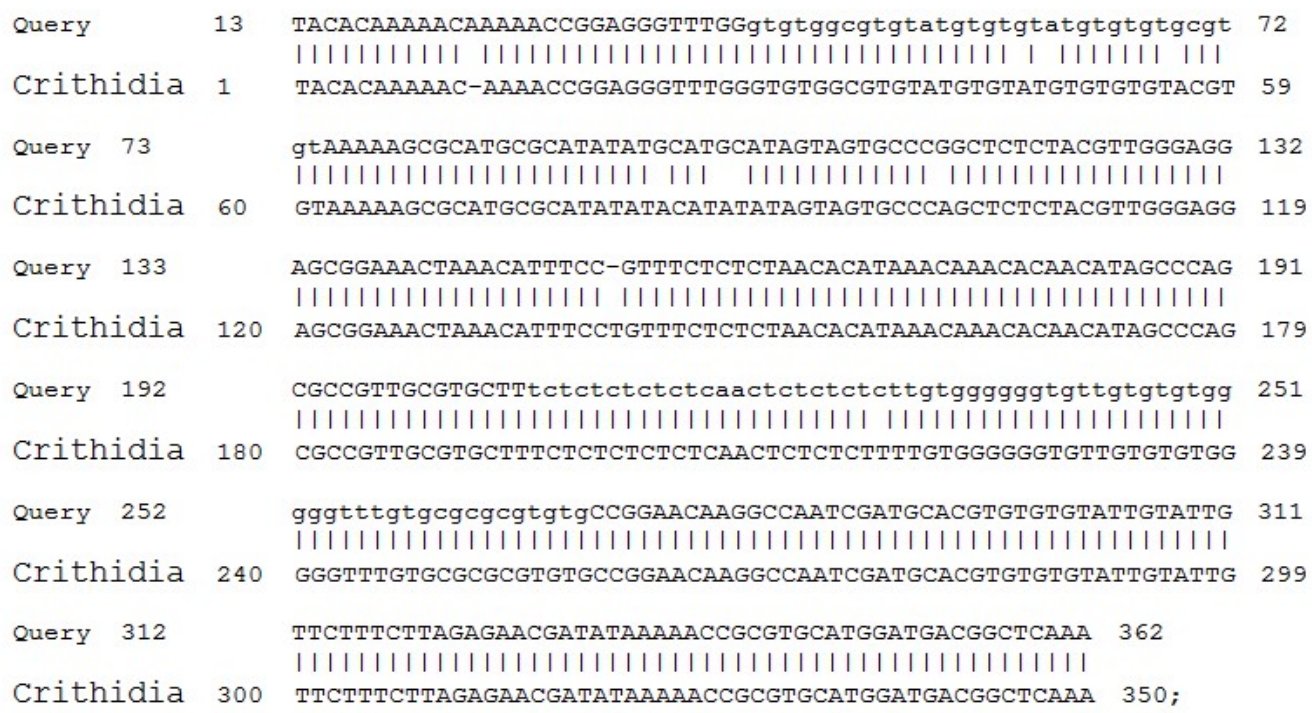


Fig.6 : Alignment of the Iraqi isolate and Crithidia luciliae with $96 \%$ similarity.

\section{الملخص العربى}

توصيف جين مفساح الاستتساخ الاخلي 1 (ITS1) للشمانيا الطفلية والمعزولة من مرضى عراقيين مصابين باللشمانيا

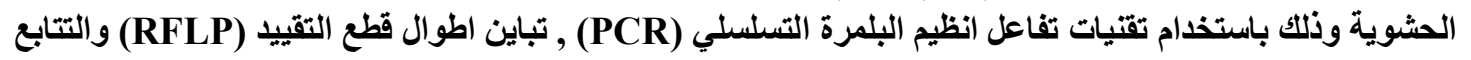

(Sequencing)

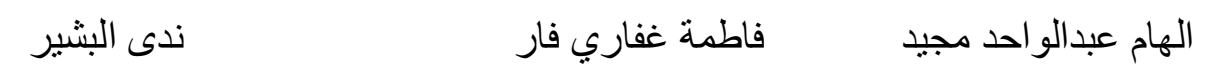

على حد علمنا لا تتوفر معلومات حول التوصيف الجزيئي للعزلة العر اقية للثمانيا الحشوية لذا هدفت هذه الدراسة توصيف العزلة العر اقية للثمانية الطفلية (Leishmania infantum) باستخدام تقنيات تفاعل انظيم البلمرة التسلسلي (PCR)) ، تباين اطوال قطع

$$
\text { التقييد (RFLP) و التتابع. }
$$

تم جمع ثلاثة عز لات من نخاع العظم لمرضى مصابين بمرض الكلا ازار ويقطنون مناطق مختلفة من بغداد. بعد التعرف على الطفيلي

تحت المجهر نم انماءها على الوسط الزرعي المحور. استخلص الدنا (DNA) لتضخيم جين مفساح الاستنساخ الداخلي -1 (ITS 1) بو اسطة تفاعل انظيم البلمرة التسلسلي (PCR). التعرف على العينات تمت در استه بتقنية تباين اطو ال قطع التقييد (RFLP)

$$
\text { (Apo } 1 \text { (هضم باستخدام انظيم الاقتطاع اجراء التتابع لناتج البلمرة. }
$$

اظهرت نتائج تفاعل انظيم البلمرة التسلسلي للعينات ان هناك حزمة تحت حوالي 500 زوج القواعد. اما نتائج تفاعل انظيم البلمرة التسلسلي مع تباين اطو ال قطع التقييد فلم تظهر اي اقتطاع باستخدام الانظيم الهاضم كما كانت نتائج التتابع مختلفة عن الجين المفصول من اللشمانيا الطفلية في بنك الجينات.

يستنتج من ذلك ان تتابع هذا الجين في اللثمانيا الطفلية المعزولة من المرضى العر اقيين تختلف تماما عن العزلة القياسية 80 / IPII) ولكن ظهر بعض التشابه مع العزلة الايرانية للثمانية الطفلية (MHOM/ TN كانت نسبة التشابه مع احد انواع الكر ايثدية (Crithidia luciliae) هي 96\%. 